\title{
The Transborder Elections in Central Europe Opportunities for Voting Abroad and the Political Integration of Immigrants*
}

\author{
BY IVÁN HALÁSZ**
}

\begin{abstract}
This paper focuses on the electoral issues relating to modern international migration. The main topics of paper are the political electoral integration of immigrants in the Central European countries and also the opportunities for voting abroad. Voting from abroad is very important possibility for the citizens living abroad and for other expatriots. The Czech, Slovak and Polish political experience in this field is relatively long, but for Hungary it is new problem which has only existed for a couple of years. At present, all Central European countries allow their citizens living abroad to vote in parliamentary elections in some form or another, while some of them also permit voting in direct presidential elections. There are two models regarding to the political integration of immigrants: The more liberal model, which is typical for Hungary and Slovakia and more restrictive Czech and Polish model. Hungary and Slovakia permit the electoral participation on the local and regional level not only for the EU citizens living there, but for the third countries nationals too. The Czech Republic and Poland have opened their local electoral level only for the EU citizens.
\end{abstract}

Keywords: Central Europe, constitution, election, emigrants, immigrants, local and regional level of participation, migration, voting abroad

\section{INTRODUCTION: CENTRAL EUROPE AND MIGRATION}

Before the big migration crisis in 2015, migration was not a major political theme in the countries of the Visegrád Group. The situation has changed dramatically one year ago, but the electoral legislation of these states was born earlier and the current crisis did not have impact on this process. The role that large immigrant communities from outside Europe play in Western Europe in the programmes of radical political parties is played out by the Roma minority in Central Europe who are the focus of propaganda of those parties and the physical assaults of local radicals.

The fact that migration (and in particular immigration) is not a definitive factor in Czech, Polish, Hungarian and Slovak discourse is largely related to the proportion of immigrants, among these countries, has only reached the EU average of $4 \%$ in the Czech Republic, $10 \%$ in Prague. ${ }^{1}$ In Hungary, the figure is around $2 \%$, and that number also includes immigrants of Hungarian descent from the Hungarian communities across the country's borders, whose culture and language do not differ from the native majority. ${ }^{2}$ In those cases, integration is very rapid, particularly now, after a right-wing conservative government made their naturalisation significantly easier. Furthermore, since 2010, anyone

* This paper was prepared with the support of the International Visegrad Fund (IVF VUSG Project No.60900011).

** Professor at the National University of Public Service, Faculty of State and Administration, and research fellow at the Hungarian Academy of Sciences, Research Center for Social Sciences, Institute of Legal Studies. E-mail: halasz.ivan@tk.mta.hu

1 Babická (2011) 179.

2 About the immigrants in Hungary and their characteristics see: Örkény, Székelyi (2010) and Kováts (2011). 
who is able to prove proficiency in the Hungarian language and Hungarian citizens among their ancestors can get Hungarian citizenship in a simplified procedure without settling in Hungary.

\section{THE GENERAL CHARACTERISTICS OF ELECTORAL LEGISLATION IN CENTRAL EUROPEAN STATES}

New, democratic electoral legislation was enacted in the entire region during the 1989/1990 transition but the regulations underwent major amendments over the last quarter of a century. One of the main reasons for this change was that the legislator introduced ballots at additional levels - particularly the European elections and regional municipal elections. However, the depth and, in particular, the frequency of changes applied to the existing, traditional types of elections i.e. parliamentary and local municipal elections, have varied a great deal from country to country.

The Polish electoral system underwent the most frequent changes, particularly at the national level. Between 1989 and 2006, the Polish people elected representatives and senators a total of six times, using four different electoral systems. ${ }^{3}$ Only the elections of 1993 and 1997 were conducted using the same rules, ${ }^{4}$ but the electoral rules were also later amended. The last set of changes was introduced in 2011, when the Polish legislator adopted a complex electoral code, which contains the regulations applicable to all conceivable political elections. The first ballot conducted in accordance with the code also took place in 2011.

In contrast, the Hungarian electoral system was changed less frequently at the parliamentary and local municipal levels..$^{5}$ There were minor amendments but until 2011, they were not sufficiently major to change the identity of electoral legislation. That only occurred in 2011 and then in 2013. First, parliament adopted the new (material) Act on Parliamentary Elections, which permitted Hungarian citizens without residential addresses in Hungary to vote on the party lists and introduced a single-round system which resembles the British model in respect of the MPs elected in individual constituencies. Naturally, the legal basis for this possibility was created by the new Fundamental Law from 2011. Then, in 2013, a new Act on Electoral Procedure was enacted, which contains the common "technical" rules regulating elections at all levels. So while in Poland, all the material and procedural electoral rules are stipulated in a single code, a heterogeneous situation has developed in Hungary- the material legislation is enacted in individual electoral laws while procedural rules are concentrated in a single law that is in effect an electoral code.

The Czech Republic and Slovakia have situations that are different to the above systems. The foundations for the most important electoral legislation of both countries were laid during the time of federal Czechoslovakia and as a result, the rules governing the election of their houses of representatives and local municipalities are similar. ${ }^{6}$ All the other electoral regulations, the Czech senate election, the presidential elections and the election of members of the European Parliament and regional municipalities were enacted after the two states separated. Accordingly, both countries had a relatively large number of individual election laws, practically a separate individual law for each legal institution and level of

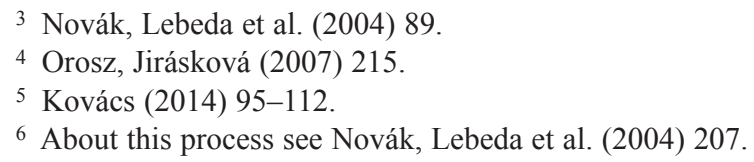


participation. Neither of these two countries separate the material and the procedural part of electoral legislation in the manner of the Hungarian system. The Czech Republic has not introduced complex codes to cover all electoral rules. The situation in Slovakia was similar but after the last reform from $2014,{ }^{7}$ Slovakia has complex electoral code for the all types of elections. The uniform electoral code was an idea of The Slovak Ministry of the Interior and the electoral legislative situation in Poland and Slovakia is currently very similar.

Another interesting aspect of the electoral history of the region: the frequency of elections. The Czech, Polish and Slovak electoral laws were passed at different times and the political cycles of individual institutions were also set differently e.g. national parliaments may be elected every four years with presidents and the European Parliament every five years, and, in addition, those countries hold regional elections and local municipal elections at different times, so, as a result, the citizens of these countries vote much more frequently than their Hungarian counterparts. Since the millennium, Slovakian citizens, whose representatives incidentally, turned their government out of office several times, only failed to vote in 2000, 2003, 2007, 2008 and 2011 and 2015. In 2009 and 2014, they have attended a total of three elections.

In Hungary, the head of state is elected by parliament, with county and local municipality elections occuring at the same time. Early elections, so far, have not taken place. That is to say, members of the Hungarian Parliament and municipal bodies of representatives (along with minority representatives since 1994) have been elected in the following years: 1990, 1994, 1998, 2002, 2010 and 2014. Local and county representatives have been elected by the population in the year of the general elections, the last time was in 2014. The Fundamental Law, adopted in 2011, increased the mandate of local municipalities from four to five years, and from 2018, the two types of elections will no longer take place in the same year.

\section{MIGRATION AND ELECTIONS}

Migration is always a two-faced affair, composed of immigration and emigration. Naturally, the two processes are closely related and both have an effect on the actual make-up and operation of the political community. Migration is usually reflected in legal regulations but the effects of emigration and immigration take different forms. At present, the question of whether expatriates without a Hungarian residential address - those who chose to emigrate as well as those Hungarian residents who are abroad at the time of elections - should be allowed to vote is largely only raised at the level of national (and perhaps European) parliamentary elections, referendums or the election of heads of state. Voting in regional or local municipal elections require a residential address within the country, as otherwise it would not be possible to decide in which municipal community the citizen concerned should belong. There are one or two exceptions, none of which are in Central Europe, where the political (electoral) integration of immigrants extends to the local and sometimes to the regional level as well.

The political integration or possibly reintegration of emigrated expatriates, ${ }^{8}$ more precisely, their inclusion of a particular sort in the political community are less questions of principle and more technical problems, at least as long as they retain their original citizenship. On the one hand, the majority of European states - and, as of now, all of the

\footnotetext{
7 See Act No. 180 from 2014 (29th May 2014).

8 And transborder kin-minorities with citizenship of the kin-state.
} 
Visegrád Four $^{9}$ - do not exclude their citizens from the parliamentary electorate when they no longer have registered residential addresses in the country. ${ }^{10}$ In effect, the national franchise is retained automatically, as long as citizenship of the country is retained. Central European countries do not apply the Anglo-Saxon solution of disenfranchising their citizens after a certain period of time living abroad e.g., the regulations of Great Britain, Australia, Canada and New Zealand. ${ }^{11}$

However, the issue raises several technical problems. For instance, is the state obliged to assist its citizens in expressing their political views, i.e. is it obliged to pursue them with a possibly virtual ballot box, or should it opt for a more neutral approach, letting those wishing to vote arrange it themselves? This would mean that, while voters are not required to establish residency in the country, they would have to be in the country on election day. On the other hand, should the state decide to make it easier for those living abroad to take part in the elections? Decisions need to be made about the method, the exact form of voting abroad that is to be permitted, the guarantees and the funds the state is prepared to invest in doing so. The general rule is also valid, the more comfortable and safe, a solution is the more it costs.

Naturally, a number of specific dilemmas of principle, of morals are raised in relation to both citizens living abroad and legally settled foreigners voting in local elections. The theory has defined several frameworks of arguments. First and most evident is the "contributivist" theory. The starting point of this theory is the contribution to the creation of public goods. This contribution can have different forms eg. form of taxes, military service, other public duties. Participation in the political decision-making always depends on this contribution. This argument is clear, logical and very popular among the population. It, however, is not a good argument because it leads back to the 19th century. There was a totally legitimate connection between the right of participation in public life and the contribution to the common goods. This classical liberal idea is very archaic for the democratic 20th century. Major achievements of democratic and humanistic development in the last fifty years is the disconnection of the the contribution and the participation. Participation became possible without contribution. ${ }^{12}$

Another problem is a question of responsibility and the role of emotion in the electoral process. Voting from abroad by citizens living permanently in a foreign country can lead to the extreme situation, when the voters might not vote on the basis of personal experience but on the basis of the grandfather's political views Voting without concrete and personal responsibility is very easy but in certain situations might not be correct. The lack of current political information in the country of origin may also cause problems. On the other hand, the modern world offers very good and cheap methods of info-communication. The internet, skype, satellite TV and cheap air fares have made it much easier for migrants to stay connected and to be politically well-informed.

According to modern and democratic conceptions, every person, who is affected by the decision of the parliament, has to have the possibility to participate in the elections. This theory is a good optimal argument for support of the enfranchisement of immigrant workers. Immigrants permanently living and taxing in the host countries are also "affected"

9 About this ,trade mark” see: Marušiak (2013).

10 See Waldrauch (2006) 359.

11 About British case see Lardy (1997) 79.

12 About the theoretical problems of this concept see Bauböck (2007) 2413-2414. and RubioMarín (2006) 124-130. 
by the political decisions and the problem is real and mental integration to the host society. This integration needs several years of residency there.

The position of the citizens living permanently abroad is very interesting. On the one hand, this theory argues against their participation in the electoral process because they are not directly affected by political decisions of their country of origin. But on the other hand, every citizen has the right to return. This right represents the core of the citizenship. If somebody has right to return to the country of his or her origin (right to repatriation), they has to have the possibility to influence the situation in this country. This aspect speaks in favor of electoral participation of citizens living abroad.

According to the last argument, it is very important that everybody has voting rights at least in one place of the world. A situation can occur, when a migrant loses the possibility of political participation in the country of his origin, but does not achieve the voting rights in the host country. Such a situation can easily happen. Finally, migrants do not have the voting rights in their native country because they are living permanently abroad yet they do not have the voting rights in the host country because they are not citizens of that country. ${ }^{13}$ Preserving voting rights in the country of origin by a migrant is more real than fast (enfranchisement) achievement of voting rights in the new homeland, at least before the naturalization.

\section{VOTING OPTIONS OF CENTRAL EUROPEAN CITIZENS LIVING ABROAD}

At present, all Central European countries allow their citizens living abroad to vote in parliamentary elections in some form while some also permit voting in direct presidential elections. This has not always been the case and the individual national systems took different routes to the present state of affairs. The Polish have the oldest traditions in the area, voting was already permitted at Polish embassies and on boats sailing under the Polish flag during communist dictatorship, although that option, which had been in existence since the 1950s, was primarily targeted, at officials, soldiers, overseas students and tourists not Polish expatriates. ${ }^{14}$

Similarly, communist Czechoslovakia began to provide opportunities for citizens, not in the country on election day, to vote at its embassies using the most traditional form of voting abroad. Interestingly, after 1990, the country took a step backwards. The new Czechoslovak parliamentary electoral law, on which the current regulations of both successor states are also based, did not permit voting abroad in any form. In that respect, both Czechoslovakia and then the Czech Republic and Slovakia differed markedly from Poland, where the possibility remained in place after 1990.

Hungary is a special case. Prior to 1989 , there was no possibility of voting abroad and it was neither introduced by the new democratic electoral regulations. The Hungarian Constitutional Court began to consider the voting rights of citizens living abroad very shortly after the transition. In 1990, the Constitutional Court ruled ${ }^{15}$ that the part of Article 2, paragraph (4) of Act no. XXXIV of 1989 on the Election of Members of Parliament that stated that "persons abroad on the day of voting" were prevented from voting was

13 Barry (2006) 52.

14 About the Polish regulation see Zbieranak (2011) 66-67.

15 See Constitutional Court Resolution no. 3/1990 (III. 4.) on the exercise of the voting rights of Hungarian citizens abroad. 
unconstitutional, and therefore it rescinded it. The provision remained in effect with the following wording: "(4) Persons without a permanent or temporary residence in Hungary are prevented from voting." This was made possible by the radically amended constitution of 1989, which made the exercise of the franchise conditional on having residency in Hungary.

This solution was unique in Central Europe Although until halfway through the first decade of the new millennium, the Czech and Slovak electoral systems did not permit voting abroad either, citizens living permanently abroad and without Czech or Slovak residency at least still had the option of visiting the country on election day and voting in a constituency after presenting their passports.

In the Czech Republic, the situation changed in 2002, because Czech citizens abroad on election day have been permitted to vote at foreign representations irrespective of whether they have residencies in the Czech Republic. That opportunity was only granted for voting for members of parliament, not for senators. Although Czech citizens living abroad and without residency in the country are permitted to vote for senators only do so if they are in the country on the day of senate elections. These citizens do not have home addresses, they can vote in the constituency of their choice and in order to be eligible, they need to hold a certificate issued by the Czech embassy in their country of residence.

The situation is highly paradoxical in respect of the senatorial elections and the imbalance that has developed will need to be addressed by the Czech legislator sooner or later. Czech citizens resident in one of the senatorial constituencies can only vote for a senator once every six years while in practice, those resident abroad can do so every two years and in the constituency of their choice. ${ }^{16}$ The 81 Czech senators have six-year mandates, but senatorial elections are held every two years in the Czech Republic because a third of the senators, must be re-elected every two years. As a result, the current system offers an opportunity for an electoral tourism and abuse of the rules, with added risk resulting from the fact that senatorial elections are traditionally characterized by very low turnouts. ${ }^{17}$

Slovakia saw a similar course of development. Slovak citizens living permanently abroad or abroad at the time of election first had the option of postal voting during the 2006 national council elections. However, with the introduction of postal voting, Slovak citizens resident abroad lost the option of voting in person in any constituency, which is still open for the direct presidential elections. At those elections, there is no option of voting by post. That difference does not appear to be particularly logical and it is probably explained by the two statues were enacted or amended at different times, with different atmospheres. The participation of the Slovak expatriots (citizens living abroad) in the election of the National Council is not very high, but increasing. ${ }^{18}$

16 Antoš (2008) 144.

17 The activity of the Czech citizens during the elections is not very intensive. Only 28 citizen from abroad registered for the election of senators in 2008. The Czech citizens living abroad are more active during the elections of the House of Representants. 6744 citizens voted in the election 2006, 8211 citizens voted during the election of parliament. Last time, in 2013 voted 10571 Czech citizens. Source of this information: Home Office of the Czech Republic and Havlík et al. (2014) 305-306.

18 Voters from abroad in the Slovak national elections - 2006: 3427 voters, 2010: 5861 voters, 2012: 7051 voters. These numbers include the Slovak citizens living abroad without permanent residency in Slovakia and the citizens with official residency in Slovakia, but living abroad. www. uszz.sk 
In recent years, Poland has also undergone major developments in the field of voting abroad. Until 2011, it was only possible to vote at foreign representations and aboard Polish ships but, due to the dynamic growth of the Polish diaspora, alternative solutions had to be given consideration. In the 2010 presidential elections, a total of 201586 Polish citizens living or working abroad cast their votes, ${ }^{19}$ resulting in tumultuous scenes at embassies in some of the more popular cities with large Polish migrant populations. That was one of the most important reasons for the Polish legislator's introduction of voting by post in 2011, not only for citizens resident abroad but also Polish citizens resident in Poland who happen to be abroad at the time of the ballot due to their work, education or other reasons. ${ }^{20}$ That was a significant easing of requirements, as foreign representations are often quite far away from the places of residence of citizens living abroad and this was the decisive motivation of the legislation - to make voting from abroad more comfortable by technical means. The motivation probably also linked to the liberal-conservative Civic Platform (PO), which was in power in 2011, being generally more popular abroad than its rival, the Law and Justice Party (PiS), particularly among Polish citizens working or studying within the EU. ${ }^{21}$

With the exception of that little private interest of the Polish liberals previous mentioned, in general the opening or widening of opportunities for voting by citizens abroad has not resulted in major disputes between politicians, either when those measures were introduced, or later on. Society, both at home and abroad, has also been rather indifferent on the issue. In the 2012 Slovak parliamentary elections, in which Slovak citizens living abroad were permitted to vote by post, a total of 728 citizens without permanent address in Slovakia registered for voting and requested the postal voting package. This number increased to 1044 voters in $2016 .{ }^{22}$ That number is a negligible proportion of the number of Slovak citizens working or studying abroad for longer terms.

The only exception in that respect is Hungary, where parliament created the opportunity for Hungarian citizens living abroad to vote in the parliamentary elections in the electoral reforms of 2011 and 2013. ${ }^{23}$ In fact, Hungarian citizens who only left the country for shorter terms and retained their residency in Hungary have been permitted to vote at Hungarian foreign representations since 2006 but not many electors actually took advantage of that opportunity in 2006 or 2010.

The situation was radically transformed after 2010, when the FIDESZ-KDNP conservative coalition won the parliamentary elections and achieved a two-thirds majority in the Parliament. That was sufficient to allow them to create a new constitution and the new majority used that entitlement and adopted the country's new Fundamental Law in 2011. ${ }^{24}$ The Fundamental Law no longer contained the provision limiting voting to those citizens of the country who have residency in the country as well. In keeping with its promise, the government coalition introduced a simplified naturalisation procedure allowing Hungarian-speaking applicants with Hungarian ancestors to get Hungarian citizenship even if they do not intend to settle in Hungary. Going back on their pre-election promises, the

19 See at $<$ http://prezydent2010.pkw.gov.pl/PZT/PL/WYN/W/index,htm > accessed 24 May 2016.

20 Zbieranek (2011) 66-67.

21 About the trends and preferencies during the Polish elections see Horváth (2014) 51-94.

${ }^{22} \mathrm{See}$ at <http://www.aktuality.sk/clanok/319373/vysledky-volieb-2016-ako-volili-slovaci-vzahranici/.> accessed 24 May 2016.

23 See Cserny (2014) 27-40.

${ }^{24}$ Halász (2011). 
coalition also allowed Hungarian citizens resident abroad to vote in the parliamentary elections in the new electoral law enacted at the end of 2011.

However, the franchise of external Hungarian citizens, and its exercise, differs from those residents in Hungary in two respects. Firstly, external Hungarian citizens may only vote after prior registration, a logical requirement. ${ }^{25}$ The other difference is that in the Hungarian system, in which all electors have two votes (one to cast for an individual candidate in an individual constituency, and one to cast for a party or minority representative of their preference), those not resident in Hungary only get one vote - they may only vote for one of the organisations on the national party list.

With that reform, Hungary joined the ranks of the majority of European states in which voting in the parliamentary elections only requires citizenship. However, the introduction of the new model caused heated, passionate political dispute between the government side and its left-wing and liberal opposition. The latter accused the governmental coalition of using the reform to get new voters, because preliminary surveys had predicted that the majority of the new external electors would support the conservatives. The prediction was in fact borne out by the results of the 2014 general elections: almost $95 \%$ of the citizens voting by post voted for the FIDESZ-KDNP block. ${ }^{26}$

The other objection, more technical in nature, concerned the issue of why voting by post, a novelty in Hungarian law, had not been also extended to Hungarian electors who maintained their residency in Hungary (and hence have two votes), but were abroad on election day and were entitled to vote at embassies. Naturally, they also had the option of coming home for the elections and vote in the constituency of their residency. Although that category includes tourists, students, diplomatic envoys, soldiers on foreign missions and similar groups, the decisive majority is formed by the new Hungarian migrants who left Hungary for various periods in search of work, most of whom are working in a member state of the European Union or in North America. This group is a new Hungarian diaspora, or at least an embryonic precursor to it. ${ }^{27}$ The size of that group is estimated at three hundred thousand people, but it may be as high as four hundred thousand ${ }^{28}$ as it is difficult to establish their number more accurately because many commute and the majority have not given up their residency in Hungary. Although Hungarian legislation prescribes that they do so if they spend a longer period abroad, failure to do so is not sanctioned and most people do forget to take that step.

It was during the election campaign that the opposition began to object to that category of electors not having the right to vote by post. They started with the premise that the number of Hungarian working abroad (mainly in the member states of EU) has increased most drastically during the last three to four years, and that therefore those people were most likely to be against the current right-wing government, whose rhetoric included

25 The government also wanted to introduce preliminary registration for citizens living in Hungary, but in 2013 the Constitutional Court pronounced that plan unconstitutional.

${ }^{26}$ Levélszavazás. See at $<\mathrm{http} / / /$ www.valasztas.hu/hu/ogyv2014/853/853_0.html> accessed 24 May 2016. Majority of postal votes came from Romania - 58330 voters have permanent adress here. The number of voters with Romanian residency is higher, because the majority of voters with e-mail adress has origin in Romania too.

27 About the problems related to this sensitive statistics see Lakatos (2015) 93-112.

28 Most végre kiderült, mennyi magyar él külföldön. HVG/Online, 15.10. 2014. According to the estimate of Hungarian Statistical Office cca. 350000 Hungarian citizens have emigrated from coutry after 1989. (Naturally, it is not political emigration). 
occasional the EU-critical elements, thus their votes would have improved the chances of the opposition parties. Therefore the opposition disapproved that members of that group could only vote at embassies, generally more costly than posting a vote. In actual fact, the number of people who indicated their wish to do so was below expectations - only about 28 thousand citizens. ${ }^{29}$ That number is a lot smaller than the 190 thousand of the almost half a million recently nationalised citizens who had registered to vote.

This argument operates in the current decision of the Hungarian constitutional court from April 2016. In its ruling of 19 April 2016, ${ }^{30}$ the Constitutional Court decreed that it is not in infringement of the Fundamental Law that the Act on Electoral Procedure does not allow voters with registered addresses in Hungary who are outside the country on voting day to vote by post. The issue was raised in a constitutional complaint that had been submitted by a Hungarian citizen resident in Great Britain who still had a registered address in Hungary. They, without the option to vote by post, would have had to travel several hundred kilometres to the Hungarian Embassy. According to the person who submitted the complaint, the regulation infringes their right to vote and represents discrimination against them, particularly in comparison with the new Hungarian nationals who received nationality after 2011, most of whom do not have registered addresses in Hungary. The political sensitivity of the issue is primarily the result has to do with the so-called "new Hungarian diaspora", created partly after 1989 and partly after 2010, most of whom still retain their registered addresses in Hungary. However, the Constitutional Court found that voting by post is only one possible way of voting, but not the only one. The right of the voter who had submitted the complaint to vote was infringed, he had an opportunity to cast both of his votes (the one for the party lists as well as the one for an individual constituency). The Constitutional Court acknowledged that casting their votes placed an extra burden on voters with registered addresses in Hungary who were outside the country on election day compared to those who do not have permanent registered addresses in Hungary, but, according to the position of the Constitutional Court, the distinction has a rational, objective, reasonable basis. Therefore it is not to be considered unconstitutional. As the voters with permanent addresses in Hungary maintain a more direct and stronger link with the Hungarian state than the other category of voters involved, resident nationals can be rightfully expected to cast their votes in person (either in Hungary or at a Hungarian foreign representation), also taking into account that their right to vote is full. They can vote for a party list as well as a candidate in an individual constituency, while those who are permitted to vote by post can only vote for a party on the party list. In their justification of their ruling, the Constitutional Court also referred to the case of Vámos v. Hungary, the European Court of Human Rights had rejected a petition that claimed an infringement of the European Convention on Human Rights on grounds essentially similar to the present case.

2928,167 citizen registered for 2014 election of MPs, but only 24,119 citizen voted (85,65 \%). The biggest Hungarian constituency is living and voting in Brussels (1675 voters), Munich (2580 voters), London (4435 voters), Bern (1196 voters), Berlin (1137 voters), Vienna (1131 voters), Haag (968 voters) and New York (680 voters). Külképviseleti szavazás See <http://www.valasztas.hu/hu/ ogyv2014/859/859_0.html > accessed 24 May 2016.

${ }^{30}$ Case IV/1578/2013, Examination of constitutional complaint regarding the right to vote and legal equality. 
The equality of electors was the issue that was raised very often in the academic debate around the new electoral system. ${ }^{31}$ Some scholars found it objectionable that two categories of citizens, had, in effect, been created - those with one and two votes. ${ }^{32}$ Certain specialists held that the solution is inconsistent with previous rulings of the European Court of Human Rights at Strasbourg. ${ }^{33}$ The best arguments for the distinction were based on the platform of proportionality. It was as if the legislator had wished to use the solution to distinguish between those who live in the country, pay taxes and contributions and would take the consequences of the decisions of the representative bodies they create and those to whom all of that does not apply but who, as citizens, can return to live in Hungary at any time under the constitution, and who may wish to cast their votes to influence future conditions in the country.

The government coalition supported the introduction of the external franchise by the argument that no distinction should be made between citizens, particularly with respect to the exercise of their political rights. According to the government, the inclusion of those living abroad in the political community was consistent with global and European trends. In addition, some government politicians also used symbolic arguments - they claimed that this was a way of achieving the political unity of the nation without any territorial changes and that the exercise of the franchise could have a purpose in forming national identities in the Hungarian communities living outside Hungary's borders.

The issue of the exact way in which Hungarian citizens living abroad would vote took some interesting turns. The matter was only decided in 2013, with the enactment of the new Electoral Procedure Act. The main problem was that a number of neighbouring states are rather unfriendly towards Hungarian policy on citizenship, particularly as Hungarian citizenship can be obtained without settling in Hungary. Incidentally, that practice is not unique in the Central European region, in fact, in Eastern Europe, it has almost become a fashion. Yet three neighbouring countries Austria, ${ }^{34}$ Slovakia $^{35}$ and Ukraine ${ }^{36}$ specifically prohibit double and multiple citizenship.

For that reason, and to partially to ensure that the Hungarian citizens living in those countries do not put their safety and their legal status there at risk by exercising their right to vote, a rather complicated voting model was created for external citizens. Officially, the Hungarian legislator moved to introduce voting by post but the model was augmented with components of voting at embassies and in Hungary as well. In practice, that meant that Hungarian citizens living abroad first registered in the electoral register then requested a

31 Bodnár (2014) 11-26.

32 During the parliamentary debate of the electoral bill in 2011, certain government MPs actually raised the idea of giving external citizens two votes as well, in line with all other Hungarian citizens. The specific solution proposed was to set up a few special individual constituencies in which only external nationals would vote for the candidates. Despite the fact that Chairman of the House László Kövér supported the model as well, the majority of the parties in government finally rejected the plan.

33 Jakab (2011) 3.

34 Waldrauch (2006) 106.

35 See Amendment of the Slovak Citizenship Act from 2010. Act No. 250/2010. (26th May 2010).

36 Szovgirja, Suklina (2007) 99-104. 
postal package that included the voting-papers. They could request to have the package delivered to their home addresses but they could also pick them up at a Hungarian embassy or in Hungary. A similar solution was adopted for voting. In the optimal default case, electors would send their votes by post, but they could also take them in person to the embassy in their country, which would forward the letters to Budapest, or they could also travel to Hungary on election day (or a few days earlier), and deposit the envelopes containing their votes at the electoral office in advance. It is important to note that the votes cast in that way at the embassies are not mixed in with the votes cast in the ballot box there, as they would be evaluated using a different process. The votes of external citizens are counted up by the National Electoral Office centrally, in a standardized manner. ${ }^{37}$

It is evident that the new Hungarian electoral system takes a very large number of criteria and multiple interests into account. As a result, it is quite complicated, particularly if also it is taken into account that the national minorities living in Hungary also elect their representatives in a preferential system. ${ }^{38}$ The more complicated a system is, the more technical problems it is likely to raise, although it seems that the 2014 elections didn't suffer any major troubles.

The electoral solutions described above indicate that transborderization of elections has reached the Central European region. Transborderization, which is closely related to processes of intense migration and the social, political, legal and mental changes engendered by globalization, is in effect a phenomenon of migration - not only of electors, but also of elections and election mechanisms. The dogma that elections can only be organised in a strictly territorial manner was not recently abandoned, was evident at the beginning of the $20^{\text {th }}$ century.

Increasingly, the leaders of countries feel that citizens of their countries must be given the opportunity to express their opinions even if they are out of the country, although in most cases, this is done with the agreement of the other states involved. This is usually expressed in electoral legislation as well, through regulations to the effect that external voting, particularly at embassies, - is to be organised only if the receiving states do not object. It is questionable whether voting by post or electronic means still falls into that category, as that does not really require much cooperation from the receiving state, and the service is conducted in a space that may be outside the territory of any state. Naturally, this may also generate disputes and disagreement as all new phenomena do, but not of an irreconcilable nature. ${ }^{39}$

37 The results of the last Parliamentary Election (6th April 2014) are very interesting the absolute majority of the Hungarian external voters registered as ,postal constituency” (without residency in Hungary) prefered the voting by embassy (111,268 voters). Only 43,056 persons sended their vote by post. 4330 voters left their vote in the polling station on the territory of Hungary. Levélszavazás. See at <http://www.valasztas.hu/hu/ogyv2014/853/853_0.html> accessed 24 May 2016.

38 A candidate on the national minority list needs only a quarter of the votes needed by a candidate on the regular party list to get into parliament. Despite that fact, in 2014, none of the national minorities managed to send a representative to parliament, although they can still send advocates with consultation rights. Currently, a total of 13 such advocates have the right to attend the National Assembly.

39 About the certain weigh of expatriots votes in Central Europe see Horváth, Skuta (2014) $61-92$. 


\section{CURRENT LEGISLATION CONCERNING THE PARTICIPATION OF IMMIGRANTS IN THE ELECTIONS OF THE V4 COUNTRIES}

All liberal democracies limit voting in some way based on citizenship and/or permanent address (residency). "While the vast majority of democratic countries, including the United States, limit voting to citizens, a significant expansion of non-citizen voting at local level has occurred in recent years." 40 This trend is typical for Europe as well, at least in the last four decades. The Central Europe has accompanied to this trend after the democratic transition in 1989/1990 and especially after the eastern enlargement of EU in 2004.

Early in 2011, the Polish Parliament adopted an ambitious electoral code regulating all types of elections that take place in Poland. This means that in the future the president, senators and members of Sejm, EP, the members of the assemblies in Polish regions, districts, settlements and municipal mayors should be elected in compliance with this code. ${ }^{41}$ The first elections under the Code took place in autumn 2011. After the new statute became effective, almost all previous partial election laws lost their legal force. ${ }^{42}$ At the same time bringing the electoral code to life was not easy because it was challenged before the Polish Constitutional Court by a group of representatives of the Law and Justice Party despite 430 Members of Parliament out of 460 members voted in its favour. ${ }^{43}$ The Code became effective only after the court's decision in the summer of 2011.

The New Code relatively precisely and in great detail regulates the issue of voting rights for foreigners and Polish citizens living or residing outside the republic. The most important definitions of the right to vote are Articles 10 and 11 of the Code. Article 10 addresses the issues of the active suffrage; Article 11 those of the passive suffrage. Pursuant to Article 10, all Polish citizens who reached 18 years of age on the election day have active electoral right in the elections of the president, senators and members of Sejm. Obviously, these must be citizens who were not stripped of their legal capacity, public rights or voting rights by the State Tribunal. ${ }^{44}$ Polish citizens and citizens of other EU member states living in Poland, who have reached the age of 18, are eligible to vote for the European Parliament. EU citizens must live permanently in the territory of the Polish Republic. Local councils can also be elected by Polish citizens and EU citizens over 18 with permanent residence in the territory of the municipality. This rule also applies to the direct election of mayors. On the other hand, deputies of district councils and assemblies (sejmiks) of voivodeships (provinces) can only be elected by Polish citizens over 18 residing within these territorialadministrative units.

Under the new Code, all Polish citizens over 21 of age can be elected in deputy elections; citizens over 30 years can take part in the election of senators and citizens over 35 of age can participate in presidential elections. The law has no mention of residence, which implies that, in principle, their place of residence may also be abroad. On the other hand, in the case of deputy candidates, the Code prescribes, in addition to active suffrage

40 Pildes (2012) 533.

41 The Polish regulation distinguishes between three types of mayor - wójt, burmistrz and prezydent miasta.

42 This was decided by a piece of legislation that introduced the new electoral code into life. Ustawa z dnia 5 stycznia 2011. (Dz. U. Z dnia 31. stycznia 2011 r.) See Art 10 of this act.

43 Zbieranek (2011) 66.

44 This specific legislative body in Poland decides legal issues of the highest state representatives. It also makes decisions on constitutional responsibility. 
and the minimum age requirement of 21 , a condition of at least 5 years' continuous residence in Poland or another EU member state. In the elections to local authorities passive suffrage has been granted to all persons with active suffrage, while only a Polish citizen who reached at least 25 years of age on the election day may run for mayor. He is then no longer required to continuously reside in the respective municipality. According to the new regulation, a person who has been lawfully sentenced to imprisonment for an officially persecuted intentional crime or a crime against the State Treasury cannot stand as a candidate. This also applies to a person whose loss of passive suffrage has been confirmed by the powers of the court under the 2006 Act on Disclosure of Documents of the State Security Organs in 1944-1990. Furthermore, an EU citizen of another country may lose passive suffrage if they have lost this right under the rules of their own country.

This amendment demonstrates that there are actually four levels of participation in the implementation of public power in Poland: the European, i.e., supranational level, the national or parliamentary level, the regional (województwo, voivodship) level, the district level and the local or municipality level. At the first level, the political community is constituted by all Polish citizens and citizens of other EU countries living in Poland. They imultaneously have active and passive suffrage. At the national level i.e., during the election of the president and both houses of Parliament - only the citizens of Poland have the right to vote, regardless of their place of residence. The situation is similar at the regional and district levels, with the only difference that the community is made up of people living there permanently - thus, citizens residing abroad may not participate in the electoral process. Finally, at the lowest, i.e. local level, the electorate is made up of citizens of Poland and other EU countries who live there permanently; however, only a citizen of the Republic of Poland may run for the office of mayor (wójt or burmistrz).

The Czech Republic has no comprehensive code regulating every type and level of election. Until recently, the president was not elected by direct vote of the people but through MPs and senators. Direct election of the president of the Czech Republic was only introduced by an amendment to the Constitution adopted early in 2012.45 Thus far, presidential elections have been mostly governed by the Constitution and the Rules of Procedure. ${ }^{46}$ Elections to local governments and counties are governed by special laws, as are the elections of members of EU Parliament.

The most important electoral law with regard to the implementation of popular sovereignty is the common Law No. 247/1995 on Elections to the Parliament of September 27, 1995, last revised in 2010. This Act regulates elections both to the Chamber of Deputies and to the Senate, although these are different from each other both in terms of time and content. The most important provisions from the perspective of this publication are those relating to immigrant policies.

This standard is of no consequence to immigrants, as in the Czech Republic, which applies relatively restrictive electoral policies to immigrants, ${ }^{47}$ the latter, citizens of other countries, do not enjoy the right to vote in the national-level parliamentary elections. This is the case almost everywhere in the world. Restrictiveness of the Czech electoral legislation is rather visible at regional and local levels for pursuant to Act 491/2001 Coll. on elections to local councils, apart from Czech citizens only citizens of those states that have signed an

45 The first direct election of president was in 2013. Winner of this election is Miloš Zeman.

46 For more detail on presidential elections see: Koudelka (2011)

47 Machová (2013) 27-33. 
international convention by which the Czech Republic is bound may vote in the Czech Republic. Currently, the only such treaty is the Treaty of Accession of the Czech Republic to the EU. This means that in the territory of the Czech Republic, in addition to their own citizens also citizens of other EU member states permanently living in the country may elect members of the local government. This does not hold for the regional level elections. Meanwhile, the Czech Republic is one of the post-transition Central and Eastern European countries with the highest proportion of immigrants. Their percentage is close to the European average $-4 \%$ of the total population. At present there are 426000 foreigners immigrants from the EU and third countries who live in the territory of the Czech Republic. ${ }^{48}$ Immigrants from the former Soviet Union and Vietnam constitute a considerable portion of the population.

The Ministry of the Interior of the Czech Republic does not keep a record of the election activity of foreign nationals-voters at the local level. There is even no information on how many foreigners were elected as local councilors in the local elections of 2004. However, there are data on electoral activity of foreigners - citizens of other EU states in the territory of the Czech Republic during the election of MEPs. For instance, in 2004, 99 citizens from EU member states had registered prior to their first elections. There were five EU citizens on the lists of Czech political parties contesting a mandate in the Czech Republic - one of them even succeeded. ${ }^{49}$ In 2009, as many as 703 citizens from other EU member states pre-registered for the election although only 318 people went to the polls. 4 EU citizens stood for a seat in the European Parliament without Czech citizenship, but none of them received a mandate. ${ }^{50}$

Prague also has a status of the region, in terms of the right to vote, election of municipal representatives of the capital is still considered municipal election. This means that citizens of other EU member states, who can also become members of the city council, can participate in the elections. At the primary municipal level i.e., not only in cities and towns but also in the districts of Prague, the citizens of other EU member states naturally have both active and passive suffrage. However, with the exception of the post of city mayor and municipal mayor since, pursuant to Act No. 128/2000 Coll. on municipalities, only a person with Czech citizenship may be a city mayor or municipality mayor or their deputy. However, regions are completely closed for foreigners-residents, regardless of their country of origin. $^{51}$

There is a certain peculiarity in an amendment on referendum. Since 1992, there has been no possibility of state-wide referendum in the Czech Republic, as this institute was opposed by the right-wingers in the process of adopting a new constitution in 1992 . Although Social Democrats and Christian Democrats repeatedly attempted to introduce this form of exercise of power, their initiative always failed. The only exception was the referendum on the accession of the Czech Republic to the EU. This, however, was only a

48 Jirásek (2010) 97.

49 They were citizens of France, Ireland, Italy, Germany and Great Britain. The mandate was given to the German citizen.

50 These were citizens of France and Italy, as well as 2 citizens of the Slovak Republic. The autor would like to express his gratitude to JUDr. Václav Henych Director of the General Administration Department, Ministry of the Interior CR and JUDr. Ján Bárta, CSc, former director of the Institute of State and Law, Academy of Sciences, CR. for providing the data on the voter turnout, as well as those on the election legislation.

51 See Act No 134/2000 Coll. on the Capital Prague. 
one-time opportunity. At the local level voters can also express their views through a plebiscite. This option is not only open to Czech citizens, but also to foreigners who have reached the age of 18 , and are registered for residence in a town or city irrespective of whether this residence is permanent or not. ${ }^{52}$ This peculiarity of the Czech regulation is probably due to differences in the time of the adoption of individual laws and to the fact that legislative bodies do not always combine or at least harmonize the content of conceptually similar laws.

Another trait or inconsistency in the Czech regulation, incidentally typical also of other countries in the region, was pointed out by Czech Constitutional lawyer Jiří Jirásek. Municipal electoral regulation requires the registration of foreigners for permanent residence in the municipality where they want to exercise their right to vote. However, the European Convention on the Participation of Foreigners in Public Life at Local Level only refers to legal residents. This concept is more general and broader than the concept of permanent residence. Legal residence can also be temporary or short-term. ${ }^{53}$ On the other hand, it is quite realistic, reasonable and proportionate to require, while securing the right to participate in local public life of potential voters to have a more lasting relationship with the municipality or city where this right is currently being exercised.

The situation described above was typical for the period before 2014. In 2014, a rather interesting debate unfolded between the Czech ombudsman and the Ministry of the Interior. Anna Šabatová ombudsman suggested the Ministry of the Interior to put the draft of the amending Act on municipal elections to the government. According to this document, all EU member state citizens (EU nationals) would have been granted with municipal voting rights, who are registered in the Czech Republic regardless of the permanent or temporary nature of their residency. The reasoning of the ombudsman was based on the inappropriate, rather exclusive, implementation of the relevant EU directive earlier by the State. As this directive does not go into details about the length of the residency in the Czech Republic, but it rules out any level of discrimination to be made between Czech citizens and other member state citizens. ${ }^{54}$

To further complicate the matter, the Czech legislator, at the time, was quite inconsistent about the regulations respective to the voting rights regarding the European Parliament elections and also the Czech municipal elections. When it came to the European Parliament elections, the Member State citizen was eligible to vote in the Czech Republic if they had proof of at least 45 days of permanent or temporary residency. EU foreigners were eligible only to vote at the municipal elections if they had permanent residency in the Czech Republic. This latter required more strict requirements. According to the ombudsman, this resulted a quite absurd situation as the Czech legislator had different understandings about the place of residence for the European Parliament elections and the local, municipal elections.

At first, the Czech Ministry of the Interior did not want to field, but eventually the whole legal dispute was sorted out by the Brno district court based on the claim of a Brnobased Slovak citizen (Peter N) just before the municipal elections in Autumn 2014. According to the district court's judgment, not only those Member State citizens with a permanent residency but also those who bear temporary Czech or Moravian residency are

52 Jirásek (2010) 109.

53 Jirásek (2010) 107-108.

${ }^{54}$ Občaní EU žijící v ČR mají právo účastnit se politického života. 23. července 2014. See at <http://www.ochrance.cz/tiskove-zpravy-2014/obcan... 1. o.>> accessed 24 May 2016. 
eligible to vote. By this, the court favoured the ombudsman. The court's decision was based on the interpretation of the relevant EU Directive, which means that the Czech regulation, in this particular case, cannot be stricter for those member state citizens who live in the country than it is in case of Czech citizens. ${ }^{55}$ Furthermore by the court the 1994 EU Directive had been inadequately implemented into the Czech Law, resulted a conflict between the national legislations and the EU legal norms. ${ }^{56}$

The horizon of Czech municipalities is completely out of the reach of foreigners. The only exception to this rule as the capital city is Prague, where the two-level or dual system of representation is in place, meaning that not only the members of the district level governments are elected by the locals but also the capital body of representatives. Such elections though are not considered as regional, but communal elections by the Czech electoral regulation, despite that Prague, as the capital city qualifies as a medium level district as well.

What is the situation in the Slovak Republic? There is a mild distinction between the regulation before and after 2014, when the Slovak parliament has adopted the new complex electoral code. The situation and regulation is relatively similar before and after 2014 . At the state-wide, national level only citizens of the Slovak Republic have voting rights in Slovakia. However, at the municipal level, the political community of persons who have the right to participate in the adoption of important political decisions is defined somewhat differently.

Currently every over-18 years old) permanent resident of city or village in Slovakia has active electoral law during the elections of local and regional municipalities (paragraphs 131 and 163 of the new electoral code). These voters may by elected as regional or local council members (see paragraphs 132 . and 164.) but only the permanent residents of city, town, village or regional district, aged $25+$ years may by elected as municipality mayor, city mayor or regional president (paragraphs 133. and 165.). The Slovak electoral legislation knows here only the notion "resident of village/city" and does not distinguish between the permanent residents and Slovak citizens. ${ }^{57}$

55 Do komunálních voleb se smí zapojit i cizinci z EU s prechodným pobytem. See at $<\mathrm{http} / /$ zpravy.idnes.cz/cizinci-se-mohou-zapojit-do-komunalnich-voleb> accessed 24 May 2016.

56 Babická (2011) 179.

57 Pursuant to Article 2 Section 1 of the former Act on elections to municipal bodies, active suffrage has enjoyed by the citizens of the Slovak Republic who have a permanent residence in a district of the Slovak capital Bratislava or a district of Košice and who reached 18 years of age no later than on the election day. In the capital of the Slovak Republic, Bratislava and in Košice, voters who was not prohibited from voting pursuant to $\S 2$, Section $2 b$ ) and d) (through the imposition of a term of imprisonment and the deprivation or restriction of legal capacity) may be elected as municipality (city) council members. In these two cities, under Article 4, a voter who is not prohibited from voting pursuant to $\S 2$, Section $2 \mathrm{~b}$ ) and d) (through the imposition of a term of imprisonment and the deprivation or restriction of legal capacity - see above) and who reached 25 years of age no later than on the election day may be elected as municipality mayor and city mayor. This means that a person who is at least 18 years of age may become a municipality or city council member while only a person over 25 years of age may become municipality mayor or city mayor. There is no mention of aliens but nor is there a mention of citizenship. Thus, foreigners residing in the municipality can count as residents alongside Slovak citizens. This is also confirmed by the provision of the municipality election law on voters' lists. The lists of voters eligible to vote in individual polling stations are compiled by municipalities, those in the capital of the Slovak Republic Bratislava and in Košice are compiled by the districts on the basis of a permanent voters' list (to the Slovak National Council, later 
The exercise of the right to vote is precluded by legal restriction of personal freedom on the grounds of protecting human health, imprisonment, deprivation of legal capacity and performance of military service or alternative service or reserve service, if required by the fulfillment of tasks under special regulations. By law, the nomination of individual candidates may be supported only by people with permanent residence in the territory of the given administrative unit. A candidate for the head of the region, for instance, requires up to 1000 such signatures. They have to be resident in the municipality that falls within the territory of the self-governing region or permanent residence in a military district that is included, for the purposes of elections, in the territory of the region. A candidate for member of the council may also run for the office of head of the regional self-government.

Thus, the provisions of individual Slovak electoral laws imply that the Slovak legislation regulates franchise depending on the level of implementation of popular sovereignty. At the nation-wide level, citizenship clearly dominates as the main and basically the only criterion (naturally, in addition to age and legal capacity). At the level of local and regional self-government, in turn, the dominating principle is permanent residence in the municipality, town and region. Even the positions of municipal mayor, city mayor and head of the regional government are not reserved to Slovak citizens so this post could theoretically be also held by foreign nationals residing in the territory of the republic. In this regard, Slovak regulation is one of the most liberal regulations in Central Europe, at least in its attitude towards participatory rights of foreigners.

In terms of openness to foreigners residing in the state's territory, Hungarian regulation seems to be closest to Slovak legislation. The new Hungarian Fundamental Law, adopted in April 2011 with effect from 1 January 2012, no longer contains restriction of the previous Constitution, according to which only Hungarian nationals could be elected mayors or chairmen of county assemblies. Thus, upon the entry into force of the new Fundamental Law, citizens of other EU member states living in Hungary may also be elected mayors and chairmen. Before 2012, there was not this possibility. For this category of electors was open only the position of the members of local and regional assemblies. The third countries nationals and recognized refugees had and have only the active electoral law in Hungary. This change has not been ruled out by the new law on local self-governments of late $2011 .^{58}$

to the National Council of the Slovak Republic). Municipality adds to the voters' list foreigners who fulfill the conditions laid down in Article 2 Section 1. Elections to the municipal government are held on the basis of universal, equal and direct suffrage by secret ballot. Elections to regional councils was regulated similarly, although a little more precisely. Act No. 303/2001 Coll. on the Elections to Regional Self-Governments, significantly amended in 2007, regulates active and passive suffrage in Articles 2 to 4 as follows: The right to vote to regional self-governments is granted to citizens of the Slovak Republic and foreign nationals who reached 18 years of age no later than on the election date and who reside in the municipality that falls within the territory of the self-governing region or to those with permanent residence in a military district, which is included, for the purposes of elections to the regional self-governments, in its territory. A person who is entitled to vote, is a resident in the municipality that falls within the respective election district and is not precluded from exercising their right to vote pursuant to $\S 2$, Section $2 \mathrm{~b}$ ) and c) may run for member of the regional self-government. A person who has the right to vote under $\S 2$, Section 1, has reached 25 years of age no later than election day and is not precluded from exercising their voting rights pursuant to $\S 2$, Section 2 b) and c) may run for the office of the head of the regional self-government.

58 2011. évi CLXXXIX. törvény Magyarország helyi önkormányzatairól. (the so-called Hungarian Local Government Act). 
To be exact, the law says nothing about the citizenship of potential municipal mayors or city mayors. In this sense, at the county and municipal level in Hungary, currently there are two categories of voters - those who possess active and passive suffrage and those who only possess active suffrage. The former category includes Hungarian citizens and citizens of EU Member States resident in the country; the latter includes refugees and immigrants third-country nationals. At the level of the national parliament, Hungary, also grants the right to vote only to its own citizens. Citizens of other EU member states are also eligible to vote in the elections to the European Parliament, in addition to its own citizens, but only if they have a registered residence in Hungary. Of course the Hungarian legislation know the general conditions of electoral law. Every voter have to be at least 18 years old. According to the Fundamental Law those disenfranchised by a court for a criminal offence or limited mental capacity do not have the right to vote and to be voted for. Citizens of another Member State of the European Union with residence in Hungary shall not have the right to be voted for if they have been excluded from the exercise of this right in their country pursuant to a legal regulation, a court decision or an authority decision of their State of citizenship. A person serving imprisonment under an absolute sentence or subject to forced medical treatment in an institute as decreed in criminal proceedings shall not be eligible to stand as candidate in any election of Members of Parliament.

\section{CONCLUSION}

The current electoral legislation of post transitional Central European countries does not represent compact model. Every country of region enables the electoral participation of the citizens living abroad in the elections on the national level. Hungary has introduced this possibility only in 2011 and 2013. More differences exist in the sphere of electoral integration of legal foreigners in these countries. Hungary and Slovakia apply the more liberal regulation, which is open towards the third countries nationals. The electoral legislation of the Czech Republic and Poland is more restrictive. The regulations of these countries allow the electoral participation only for the citizens of EU member states and only on the local level. The relative liberalism of the Hungarian and Slovak electoral legislation does not mean more liberal immigrational policy, than the similar policy of the other Visegrad countries. This attitude is more or less the consequence of the concrete circumstances in the time of adoption of current electoral regulation. The Hungarian regulation was born in the optimistic years of complex political and social transition after the collapse of communism, the Slovak legislation after the collapse of the problematic political regime of Vladimir Mečiar prime-minister (1992-1998). The possible effects and influence of the last migrational crisis from 2015 on the electoral regulation of affected states is open question yet.

\section{LITERATURE}

Antoš, M., Principy voleb v České republice (Linde 2008).

Babická, K., 'Pracovní migrace do České republiky' in HCh Scheu (ed), Migrace a kulturní konflikty (Auditorium 2011).

Barry, K., 'Home and Away. Construction of Citizenship in Emigration Context' (2006) 1 New York University Law Review 11-59.

Bauböck, R., 'Stakeholder Citizenship and Transnational Political Participation: A Normative Evaluation Of External Voting' (2007) 5 Fordham Law Review 2413-2414.

Bodnár, E., 'A határontúliak választójogának egyenlősége' in A Cserny (ed), Határtalan választások (NKE 2014) 11-26. 
Cserny, A., 'Gondolatok a külhoni állampolgárok választójogának gyakorlásával összefüggő egyes kérdésekröl' in A Cserny (ed), Határtalan választások (NKE 2014) 27-40.

Halász, I., 'Creation and Characteristics of the new Fundamental Law of Hungary' (2011) 2 The Lawyer Quarterly 85-105.

Havlík, V. et al., Volby do Poslanecké sněmovny (MUNI Press 2014).

HVG/Online, 15.10. 2014. <http://hvg.hu/gazdasag/20141015_Most_vegre_kiderult_mennyi magyar_el kulf> 24 May 2016.

Jakab, A., ‘A külföldön élő magyar állampolgárok választójoga egyenlőségének kérdése a választási törvény koncepciójában’ (2011) 38 Pázmány Law Working Papers 1-4.

Jirásek, J., 'Ústavní statut cizinců v České republice' in J Jirásek (ed), Listina a současnost (Faculty of Law, PU, Olomouc 2010).

Kováts, A. (ed), Magyarrá válni (KI 2011).

Kovács, L. I., 'A választójog külhoni magyarokra történő kiterjesztésének folyamata a rendszerváltást követően' in A Cserny (ed), Határtalan választások (NKE 2014) 95-112.

Lakatos, J., 'Külföldön dolgozó magyarok, Magyarországon dolgozó külföldiek' (2015) 2 Statisztikai Szemle 93-112.

Lardy, H., 'Citizenship and the Right to Vote' (1997) 1 Oxford Journal of Legal Studies 75-100.

Marušiak, J. et al., 'Is Visegrad Still a Central European „Trade Mark”?' (VEDA Publishing House 2013).

Horváth, A., 'Eltérő preferenciák: a külhoni szavazatok mintázata Lengyelországban és Csehországban' in I Halász (ed), A migránsok politikai integrációja a visegrádi államokban (NKE 2014) 51-94.

Koudelka, Z., Prezident republiky (Legis 2011).

Machová, Z., Volebni právo cizincưv komunálnich volbách České republiky a jeho využití (UK v Praze - Nakl. Karolinum 2013).

Novák, M., Lebeda, T. et al., Volebni a stranické systémy. ČR v mezinárodním srovnání (Vyd. a nakl. Aleš Čeněk 2004).

Orosz, L., Jirásková, V., Ústavné právo porovnávacie (UPJŠ 2007).

Örkény, A., Székelyi, M. (eds), Az idegen Magyarország (ELTE Eötvös Kiadó 2010).

Pildes, H. R., 'Elections' in M Rosenfeld, A Sajó (eds), The Oxford Handbook of Comparative Constitutional Law (Oxford University Press 2012).

Rubio-Marín, R., 'Transnational Politics and the Democratic Nation-State. Normative Challanges of Expatriots Voting and Nationality Retention of Emigrants' (2006) 1 New York University Law Review 124-130.

Szovgirja, O. V., Suklina, N. G., Konsztyitucijne pravo Ukrainy (Jurinkom Inter 2007).

Horváth, A., Skuta, V., 'Szimbolikus gesztus vagy érdemi befolyás? A migráns szavazatok súlya és megoszlása a visegrádi államokban' in A Cserny (ed), Határtalan választások (NKE 2014) 61-92.

Waldrauch, H., 'Rights for Expatriots, Multiple Citizens and Resticted Citizenship for Certain nationals' in R Baübock, E Ersboll, K Gronedijk, H Waldrauch (eds), Acquisition and Loss of Nationality: Policies and Trends in 15 European Countries (Amsterdam University Press 2006), 359-384.

Waldrauch, H., 'Acquisition of nationality at birth and by naturalisation in Western Europe' in $\mathrm{R}$ Bauböck (ed), Migration and Citizenship. Legal Status, Rights and Political Participation (Amstrerdam University Press 2006), 106-109.

Zbieranek, J., 'Nowe procedury: glosowanie korespondencyjne i przez pelnomocnika' in K Skotnicki (ed) Kodeks wyborczy. Wstepna ocena (Wydawnictwo Sejmowe 2011). 